\author{
Danuta Janczewska \\ Społeczna Wyższa Szkoła Przedsiębiorczości \\ i Zarządzania w Łodzi
}

\title{
Uwarunkowania rozwoju przedsiębiorstwa uczącego się na przykładzie sektora MŚP
}

Dynamika zmian rynku oraz szeroko rozumianego otoczenia przedsiębiorstwa wymusza poszukiwanie nowych kierunków rozwoju przedsiębiorstwa w sektorze MŚP głównie poprzez innowacje oraz wiedzę. Na podstawie strategii lizbońskiej oraz założeń budowy gospodarki opartej na wiedzy (GOW, ang. knowledge based economy) w krajach członkowskich Unii Europejskich sformułowane zostały prognozy nakładów na B+R. W Polsce nakłady te powinny osiągnąć w roku 2006 poziom 1,5\% PKB, jednak w kolejnych latach formułowano niższe, bardziej realistyczne cele, np. $0,92 \% \mathrm{w}$ roku 2010 , który to poziom również okazał się za wysoki (Sulmicka 2010).

W świetle niskich wydatków na sferę badawczo-rozwojową ze strony państwa szczególnie istotne staje się podnoszenie poziomu wiedzy na poziomie przedsiębiorstw. Pojęcie organizacji uczącej się, organizacji inteligentnej, może być rozumiane jako proces tworzenia systemowych rozwiązań w przedsiębiorstwie poprzez kształtowanie struktury komunikacji, informacji oraz budowanie interakcji pomiędzy uczestnikami systemu. Organizacja ucząca się opiera się na pewnej sumie wiedzy, którą dysponują poszczególni pracownicy, można także zidentyfikować charakterystyczne cechy będące efektem określonych działań w obszarze zarządzania przedsiębiorstwem.

Jednym ze współczesnych sposobów podnoszenia pozycji konkurencyjnej przedsiębiorstwa MŚP jest doskonalenie przedsiębiorczości oraz działań przedsiębiorczych poprzez uczenie się organizacji. Badania własne sektora MŚP ukazują możliwość zwiększenia dynamiki rozwoju firm MŚP w tworzeniu innowacji. Działania i tendencje występujące w tym sektorze wskazują na możliwość powiększania zasobów wiedzy poprzez tworzenie sieci współpracy oraz wymianę doświadczeń przedsiębiorczych firm MŚP z wykorzystaniem nowoczesnych technik informacyjnych. Celem niniejszego artykułu jest prezentacja procesu uczenia się przedsiębiorstwa MŚP oraz identyfikacja czynników wpływających na jego przebieg.

\section{Badania zapotrzebowania na wiedzę przedsiębiorstw w sektorze MŚP}

W roku 2009 liczba zarejestrowanych przedsiębiorstw MŚP w Polsce wynosiła 3880 tys., z czego 94,7\% stanowiły przedsiębiorstwa mikro, zatrudniające do dziewięciu osób. Firmy małe stanowiły 4,4\%, a średnie $0,8 \%$. W ujęciu strukturalnym jedynie $11 \%$ firm w sektorze MŚP stanowiły firmy produkcyjne, natomiast $89 \%$ przedsiębiorstw deklarowało działalność usługową. Udział sektora MŚP w tworzeniu PKB w roku 2008 wynosił 46,9\% (PARP 2010). Zarówno liczba przedsiębiorstw MŚP, jak i ich udział w tworzeniu dochodu narodowego wskazują na ich zasadnicze znaczenie dla rozwoju gospodarki. Rozwój gospodarczy związany jest 
z budową GOW, w perspektywie celów Unii Europejskiej do roku 2020 - głównym celem jest kreowanie przedsiębiorstwa inteligentnego, uczącego się.

Powstaje zatem pytanie, czy sektor MŚP można analizować w aspekcie cech przedsiębiorstwa uczącego się oraz jakie kategorie uwarunkowań mogą stymulować rozwój przedsiębiorstwa MŚP.

Badania prowadzone przez PARP w latach 2008-2009 wskazały na kluczowe umiejętności i znaczenie zasobów wiedzy niezbędnej w prowadzeniu własnego przedsiębiorstwa (PARP 2010). Wyszukiwanie informacji strategicznych, przekształcanie ich w wiedzę niezbędną do prowadzenia przedsiębiorstwa nie jest zjawiskiem powszechnym wśród MŚP według badań PARP. Około $17 \%$ badanych MŚP w ogóle nie poszukiwało i nie korzystało z żadnego typu informacji strategicznych. W opinii badanych, najczęściej poszukiwaną informacją jest ta, która umożliwia kontynuowanie działalności dotychczasowej oraz wskazuje sposoby zarabiania pieniędzy. Wśród najważniejszych umiejętności, które należy kształcić, przedsiębiorcy wskazywali: wiedzę na temat pozyskiwania funduszy na prowadzenie firmy, umiejętność tworzenia strategii firmy, znajomość technik tworzenia biznesplanów, technik marketingowych i analizy potrzeb klientów, reklamowanie produktu, sprzedaż, wiedzę na temat wymogów oraz przepisów prawnych dotyczących prowadzenia firmy, umiejętność prowadzenia negocjacji. Inne badania PARP z roku 2009, dotyczące znaczenia informacji strategicznych w działalności przedsiębiorstw dowiodły, że przedsiębiorcy z sektora MŚP poszukują informacji, które mogą wpłynąć na strategię przedsiębiorstw, a także o nowych technologiach i klientach, konkurentach oraz aktualnych klientach. Niewielka grupa badanych wskazywała też na poszukiwanie informacji o otoczeniu międzynarodowym firmy.

Wiodąca rola zasobów wiedzy w rozwoju gospodarczym oraz kwalifikacje i kompetencje kadry pracowniczej osiągane mogą być w MŚP poprzez edukację i szkolenia. Współcześnie dominuje teoria o możliwości budowania przewagi konkurencyjnej przedsiębiorstw z sektora MŚP na podstawie czynników niematerialnych, głównie związanych z kwalifikacjami i kompetencjami pracowników. W odniesieniu do sektora MŚP podnoszenie konkurencyjności uwarunkowane jest możliwością realizacji procesu budowania zasobów wiedzy w przedsiębiorstwach z sektora MŚP oraz przekształcania przedsiębiorstwa w organizację inteligentną.

\section{Cechy przedsiębiorstwa inteligentnego}

Koncepcja organizacji inteligentnej powstała w USA, Szwajcarii, Niemczech i Francji. Dotyczy ona organizacji doskonalącej się i posiadającej umiejętności uczenia się. Przyjmuje się, że każda organizacja posiada określony poziom inteligencji, pozwalający na dostosowanie się jej do otoczenia, ułatwia jej członkom proces uczenia się i podlega ciągłym transformacjom. Koncepcję tę uzupełnia pojęcie węzła kompetencji koordynujących postępowanie i rozwój przedsiębiorstwa inteligentnego (Grudzewski, Hejduk 1999).

Generowanie wiedzy w przedsiębiorstwie inteligentnym następuje w wyniku koordynacji i wzajemnego oddziaływania czterech cykli:

- I cykl - poznanie: przyswojenie - zrozumienie,

- II cykl - adaptacja: myślenie - komunikacja,

- III cykl - innowacyjność: nauczanie - rozwiązywanie,

- IV cykl - realizacja: wartość - zachowanie.

Obszarem wspólnym wszystkich czterech cykli jest wiedza, która prowadzi do osiągania wysokich wskaźników efektywności organizacji.

System wysokiej inteligencji tworzy cała organizacja (Penc 2000), która rozwija jednocześnie obszary, takie jak: inteligencja informacyjna, technologiczna, innowacyjna, finansowa, marketingowa i organizacyjna. Współczesne problemy z otoczeniem przedsiębiorstwa narzucają 
konieczność wykształcenia inteligencji logistycznej. W modelu organizacji inteligentnej rozwijanie poszczególnych sfer odbywa się poprzez działanie kształtujące (tab. 1).

Tab. 1. Działania kształtujące inteligencję organizacji

\begin{tabular}{|c|c|c|c|}
\hline $\begin{array}{l}\text { Sfery inteligen- } \\
\text { cji organizacji }\end{array}$ & Działania kształtujące & Wpływ na organizację & Efekt rynkowy \\
\hline $\begin{array}{l}\text { Inteligencja } \\
\text { informacyjna }\end{array}$ & $\begin{array}{l}\text { Szybkie pozyskiwanie } \\
\text { informacji, gromadzenie } \\
\text { ich i przetwarzanie, } \\
\text { przesyłanie informacji } \\
\text { do właściwego szczebla }\end{array}$ & $\begin{array}{l}\text { Ułatwianie procesu } \\
\text { decyzyjnego }\end{array}$ & $\begin{array}{l}\text { Sprawniejsze zarządzanie } \\
\text { firmą prowadzi do obej- } \\
\text { mowania konkurencyjnych } \\
\text { pozycji rynkowych }\end{array}$ \\
\hline $\begin{array}{l}\text { Inteligencja } \\
\text { technologiczna }\end{array}$ & $\begin{array}{l}\text { Tworzenie, wyszukiwanie } \\
\text { i nabywanie właściwych } \\
\text { technologii oraz } \\
\text { wykorzystywanie ich }\end{array}$ & $\begin{array}{l}\text { Uzyskanie wyrobów } \\
\text { wysokiej jakości }\end{array}$ & $\begin{array}{l}\text { Rozwijanie nowych dzie- } \\
\text { dzin produkcji, przywódz- } \\
\text { two technologiczne } \\
\text { na rynku }\end{array}$ \\
\hline $\begin{array}{l}\text { Inteligencja } \\
\text { innowacyjna }\end{array}$ & $\begin{array}{l}\text { Poszukiwanie innowacyj- } \\
\text { nych rozwiązań, tworze- } \\
\text { nie korzystnych warun- } \\
\text { ków finansowych } \\
\text { i motywacyjnych }\end{array}$ & $\begin{array}{l}\text { Promowanie innowacji } \\
\text { wpływa na kreatywne } \\
\text { zachowanie się } \\
\text { pracowników }\end{array}$ & $\begin{array}{l}\text { Firma aspiruje do roli } \\
\text { firmy innowacyjnej } \\
\text { i lidera innowacji } \\
\text { na rynku }\end{array}$ \\
\hline $\begin{array}{l}\text { Inteligencja } \\
\text { finansowa }\end{array}$ & $\begin{array}{l}\text { Umiejętne gospodarowa- } \\
\text { nie finansami, racjonalne } \\
\text { dzielenie i wydatkowanie }\end{array}$ & $\begin{array}{l}\text { Możliwość inwestycji } \\
\text { prowadzi do poprawy } \\
\text { warunków funkcjonowa- } \\
\text { nia firmy }\end{array}$ & $\begin{array}{l}\text { Wzrost zasobów finanso- } \\
\text { wych pozwala na zajęcie } \\
\text { pozycji lidera na rynku }\end{array}$ \\
\hline $\begin{array}{l}\text { Inteligencja } \\
\text { marketingowa }\end{array}$ & $\begin{array}{l}\text { Stałe badanie rynku, } \\
\text { identyfikacja potrzeb } \\
\text { nabywców, wyszukiwanie } \\
\text { nisz rynkowych }\end{array}$ & $\begin{array}{l}\text { Stosowanie metod } \\
\text { zarządzania } \\
\text { marketingowego prowadzi } \\
\text { do lepszego wykorzysta- } \\
\text { nia zasobów firmy }\end{array}$ & $\begin{array}{l}\text { Dzięki zarządzaniu } \\
\text { zorientowanemu na rynek } \\
\text { firma zajmuje wiodąca } \\
\text { pozycję na rynku, wzrasta } \\
\text { liczba jej klientów }\end{array}$ \\
\hline $\begin{array}{l}\text { Inteligencja } \\
\text { logistyczna }\end{array}$ & $\begin{array}{l}\text { Stałe doskonalenie } \\
\text { procesów logistycznych } \\
\text { w przedsiębiorstwie }\end{array}$ & $\begin{array}{l}\text { Poprawa efektywności } \\
\text { funkcjonowania firmy } \\
\text { dzięki sprawniejszemu } \\
\text { realizowaniu działań }\end{array}$ & $\begin{array}{l}\text { Zajęcie pozycji lidera } \\
\text { w zakresie produkcji, } \\
\text { dystrybucji itd. }\end{array}$ \\
\hline $\begin{array}{l}\text { Inteligencja } \\
\text { organizacyjna }\end{array}$ & $\begin{array}{l}\text { Dynamiczne dostosowy- } \\
\text { wanie organizacji } \\
\text { do warunków otoczenia, } \\
\text { zmiana struktur, hierarchii } \\
\text { organizacyjnej, tworzenie } \\
\text { nowych struktur }\end{array}$ & $\begin{array}{l}\text { Doskonała komunikacja } \\
\text { wewnątrz organizacji, } \\
\text { lepsze funkcjonowanie } \\
\text { i wyższa efektywność } \\
\text { organizacji }\end{array}$ & $\begin{array}{l}\text { Szybsze reagowanie } \\
\text { na potrzeby rynku oraz } \\
\text { na zmiany w otoczeniu } \\
\text { organizacji, wyprzedzanie } \\
\text { konkurentów, zajmowanie } \\
\text { pozycji lidera }\end{array}$ \\
\hline $\begin{array}{l}\text { Inteligencja } \\
\text { społeczna }\end{array}$ & $\begin{array}{l}\text { Szczególna troska o zat- } \\
\text { rudnionych pracowników } \\
\text { i społeczeństwo (społecz- } \\
\text { na odpowiedzialność } \\
\text { biznesu) }\end{array}$ & $\begin{array}{l}\text { Doskonalenie warunków } \\
\text { pracy, tworzenie } \\
\text { warunków do awansów } \\
\text { i delegowania uprawnień }\end{array}$ & $\begin{array}{l}\text { Wzrost zadowolenia pra- } \\
\text { cowników przekłada się } \\
\text { na większe zaangażowa- } \\
\text { nie w realizację celów } \\
\text { organizacji }\end{array}$ \\
\hline $\begin{array}{l}\text { Inteligencja } \\
\text { ekologiczna }\end{array}$ & $\begin{array}{l}\text { Troska o środowisko, } \\
\text { zarządzanie ekologiczne, } \\
\text { identyfikacja czynników } \\
\text { zagrażających środowisku }\end{array}$ & $\begin{array}{l}\text { Zmniejszenie zagrożenia } \\
\text { dla środowiska, poprawa } \\
\text { wizerunku organizacji }\end{array}$ & $\begin{array}{l}\text { Wzrost zainteresowania } \\
\text { organizacją, uznanie, } \\
\text { popularność oraz wzrost } \\
\text { pozycji rynkowej }\end{array}$ \\
\hline
\end{tabular}

Źródło: opracowanie własne na podstawie: Grudzewski, Hejduk 1999, s. 251. 
Można sformułować pewne uogólnienie, dotyczące sumowania poszczególnych rodzajów inteligencji organizacji do poziomu inteligencji ogólnej. Można też przyjąć założenie, że różny jest udział poszczególnych kategorii w inteligencji ogólnej, tworzącej pewną wartość dodaną, której poziom będzie decydował o gotowości do podejmowania przez przedsiębiorstwo walki konkurencyjnej na rynku.

Warunkiem podjęcia działań konkurencyjnych, a tym samym atrybutem przedsiębiorstwa inteligentnego, jest umiejętność wykorzystania posiadanej wiedzy oraz dążenie do powiększania jej zasobów poprzez zbieranie informacji.

\section{Użyteczność kapitału intelektualnego opartego na wiedzy}

Dobra ekonomiczne, którymi są informacja oraz wiedza, posiadają określoną użyteczność (Boisot, Canals 2004). Otaczający świat może być opisany poprzez zbiór twierdzeń, których suma staje się zasobem wiedzy. Pojawiające się nowe informacje wprowadzają modyfikacje do posiadanych zasobów wiedzy - w takim kontekście można rozpatrywać użyteczność informacji. Informacje jako takie stanowią nieuporządkowany, niezbilansowany i niekompletny zbiór, mogący po uporządkowaniu stanowić potencjał wyjściowy do budowania lub uzupełniania zasobu wiedzy. Zdaniem Pomykalskiego, wartością nie jest zdobywanie wielu informacji, lecz zdobywanie infomracji możliwie, ale właściwych (Pomykalski 2001).

Kapitał intelektualny przedsiębiorstwa oparty na zasobach wiedzy składa się z następujących elementów: kapitał strukturalny, kapitał ludzki, przywództwo, kultura i wartość przedsiębiorstwa (Edvinsson, Malone 2001). Pojęcie kapitału intelektualnego przedsiębiorstwa znalazło uzasadnienie w wycenie jego aktywów niematerialnych, w których wiedza, doświadczenie czy potencjał innowacyjny są wyceniane znacznie wyżej niż zasoby infrastrukturalne (Edvinsson, Malone 2001). Powstawanie trzech podstawowych form kapitału intelektualnego, wymienianych przez Edvinssona i Malone, można objaśnić w ujęciu procesowym, jako budowanie:

- kapitału ludzkiego - poprzez kumulowanie umiejętności, wiedzy i doświadczeń pracowników - w ujęciu dynamicznym,

- kapitału strukturalnego - poprzez ciągłe doskonalenie kapitału organizacyjnego, kapitału innowacyjnego oraz kapitału procesów w przedsiębiorstwie,

- kapitału klienckiego - poprzez budowanie właściwych relacji oraz kontaktów przedsiębiorstwa z jego klientami.

Zamiast kapitału klienckiego inni badacze stosują określenie struktura zewnętrzna oraz struktura wewnętrzna. Trzy obszary kapitału intelektualnego przedsiębiorstwa stają się wartością finansową, jeżeli przedsiębiorstwo potrafi je wykorzystać w celu wzrostu zasobów wiedzy, poprawy pozycji konkurencyjnej i finansowej.

Umiejętne wykorzystanie zasobów wiedzy predestynuje przedsiębiorstwo do miana przedsiębiorstwa inteligentnego - zatem firmy inteligentne to organizacje, które posiadają określone zasoby wiedzy, poszukują informacji niezbędnych do rozwijania przedsiębiorstwa oraz potrafią absorbować informacje zwiększające kapitał wiedzy. Wiedza jako zasób niematerialny w firmie powinna być wykorzystywana poprzez projektowanie nowych produktów, nowych technologii i procesów - w celu osiągania wzrostu ekonomicznego, wysokiej pozycji rynkowej przedsiębiorstwa oraz wspomagania działań konkurencyjne na rynku, w tym oferowania konkurencyjnych cen, lepszych warunków dostaw, lepszej organizacji logistyki. W odniesieniu do przedsiębiorstw z sektora MŚP należy wskazać na szczególną pozycję zasobów wiedzy w aspekcie mniejszej dostępności pozostałych zasobów związanych z kapitałem ludzkim - w ujęciu Edvinssona i Malone (Edvinsson, Malone 2001) - czy kapitału strukturalnego i klienckiego. 
Wiedza powstaje przy współudziale wszystkich pracowników, kreujących i zdobywających wiedzę, w tym również wnoszących swój wkład w postaci doświadczeń i umiejętności. Uznaje się, że zasoby wiedzy powstają podczas procesu ciągłego podnoszenia kwalifikacji pracowników, udziału w szkoleniach i studiach oraz wykorzystaniu zdobytej wiedzy wewnątrz firmy. Współpraca i dzielenie się wiedzą przez pracowników w przedsiębiorstwie jest częścią procesu kreowania nowej wiedzy i daje w efekcie synergiczny wzrost zasobu wiedzy. Udział całej organizacji w procesie tworzenia i powiększania zasobów wiedzy jest atrybutem organizacji inteligentnej. Miarą zapotrzebowania na wiedzę może być liczba pracowników podejmujących studia, uczestniczących w szkoleniach lub zajmujących się gromadzeniem informacji i przetwarzających je na zasoby - kapitał wiedzy.

Źródłem informacji dla pracowników w przedsiębiorstwie mogą być:

- źródła pierwotne: książki, czasopisma, patenty, opublikowane raporty, normy, specyfikacje, ustawy, wewnętrzne raporty przedsiębiorstw, projekty techniczne i referaty naukowe (Pomykalski 2001),

- źródła wtórne: czasopisma abstraktów, informatory o publikacjach,

- obserwacje,

- konsultacje,

- powiadomienia o osiągnięciach naukowo-badawczych,

- udział w przedsięwzięciach $\mathrm{B}+\mathrm{R}$.

Aktualnie udział w przedsięwzięciach z udziałem sfery nauki nie są dla przedsiębiorstw z sektora MŚP niedostępne, ze względu na specjalne projekty innowacyjne, w których współpraca innowacyjna firm MŚP i instytucji naukowych są finansowane przez Unię Europejską. Inwestycją w wiedzę są zatem wydatki na działalność badawczo-rozwojową (B+R), zakup know-how, licencji oraz technologii. Wiedzochłonność przedsiębiorstwa lub branży może być definiowana poprzez nakłady finansowe przeznaczone na działalność innowacyjną (Białoń, Janczewska 2007). W procesach innowacyjnych - szczególnie w gospodarce opartej na wiedzy - ważnym elementem dynamizującym ich rozwój jest pierwiastek intelektualny. Pierwiastek intelektualny jest pojęciem agregatowym. W różnych organizacjach występują takie jego elementy, jak:

- gromadzenie wiedzy potrzebnej do realizowania działalności rozwojowej wszelkich form aktywności ludzkiej,

- ciągłe uzupełnianie i nabywanie nowej wiedzy i nowych umiejętności oraz wiadomości, a więc poszukiwanie źródeł innowacji,

- tworzenie własnego zaplecza badawczo-rozwojowego,

- wprowadzanie nowych projektów i usprawnień organizacyjnych,

- projektowanie nowych technologii,

- wspólne opracowanie sfery przemysłu i sfery B+R .

W odniesieniu do przedsiębiorstw z sektora MŚP określenie pierwiastka intelektualnego w działalności opartej na wiedzy jest zindywidualizowane i zależy od wielkości firmy oraz relacji z szeroko pojętym rynkiem.

Charakterystyka poszczególnych elementów pierwiastka intelektualnego na przykładzie przedsiębiorstwa MŚP w przemyśle spożywczym (branża cukiernicza) została pokazana w tabeli 2. Analiza poszczególnych wierszy pozwala na zdefiniowanie procesów składających się na zasoby intelektualne prezentowanego przedsiębiorstwa. Firma zajmuje się produkcją czekolady z przeznaczeniem do dalszego przerobu w innych zakładach cukierniczych oraz produkcją czekolady w tabliczkach, przeznaczonej do sprzedaży detalicznej. 
Tab. 2. Charakterystyka elementów składowych pierwiastka intelektualnego w przedsiębiorstwie MŚP na przykładzie branży cukierniczej ${ }^{1}$

\begin{tabular}{|c|c|c|c|c|}
\hline \begin{tabular}{|c|} 
Elementy \\
pierwiastka \\
intelektualnego
\end{tabular} & Przejawy działań & $\begin{array}{c}\text { Osoby } \\
\text { odpowiedzialne }\end{array}$ & $\begin{array}{c}\text { Czas trwania } \\
\text { dzialania }\end{array}$ & Efekty działań \\
\hline $\begin{array}{l}\text { Gromadzenie } \\
\text { wiedzy }\end{array}$ & $\begin{array}{l}\text { Zatrudnianie osób } \\
\text { z wyższym wykształ- } \\
\text { ceniem, posiadających } \\
\text { doświadczenie } \\
\text { i kwalifikacje; } \\
\text { tworzenie kanałów } \\
\text { wymiany wiedzy } \\
\text { w firmie }\end{array}$ & $\begin{array}{l}\text { Właściciel, } \\
\text { kierownik } \\
\text { działu } \\
\text { personalnego }\end{array}$ & $\begin{array}{l}2-3 \text { lata } \\
\text { i trwa nadal }\end{array}$ & $\begin{array}{l}\text { Posiadanie wykształco- } \\
\text { nej kadry, posiadającej } \\
\text { wiedzę na temat tech- } \\
\text { nologii, techniki, marke- } \\
\text { tingu, kontrola fluktuacji } \\
\text { kadr wiedzy; przepływ } \\
\text { wiedzy pomiędzy } \\
\text { komórkami organizacyj- } \\
\text { nymi }\end{array}$ \\
\hline $\begin{array}{l}\text { Uzupełnianie } \\
\text { i nabywanie } \\
\text { nowej wiedzy }\end{array}$ & $\begin{array}{l}\text { Organizowanie } \\
\text { szkoleń, kursów, } \\
\text { warsztatów, wyjazdów, } \\
\text { udział w targach } \\
\text { i wystawach }\end{array}$ & \begin{tabular}{|l|} 
Właściciel, \\
kierownicy \\
poszczególnych \\
komórek \\
organizacyjnych
\end{tabular} & Proces ciągły & $\begin{array}{l}\text { Uzyskiwanie certyfika- } \\
\text { tów, osiąganie wyższych } \\
\text { kwalifikacji, poszerzenie } \\
\text { wiedzy o nowe techniki, } \\
\text { technologie czy } \\
\text { narzędzia marketingowe }\end{array}$ \\
\hline $\begin{array}{l}\text { Tworzenie } \\
\text { własnego } \\
\text { zaplecza } \\
\text { badawczo- } \\
\text {-rozwojowego }\end{array}$ & $\begin{array}{l}\text { Organizowanie } \\
\text { własnego laborato- } \\
\text { rium, warsztatu } \\
\text { technicznego, biura } \\
\text { projektów }\end{array}$ & \begin{tabular}{|l|} 
Dyrektor \\
techniczny, \\
dyrektor \\
ds. marketingu
\end{tabular} & $\begin{array}{l}5 \text { lat i trwa } \\
\text { nadal }\end{array}$ & $\begin{array}{l}\text { Możliwość zaprojekto- } \\
\text { wania i testowania } \\
\text { nowych produktów czy } \\
\text { technologii na podstawie } \\
\text { własnego zaplecza } \\
\text { badawczo-rozwojowego }\end{array}$ \\
\hline \begin{tabular}{|l|} 
Wprowadzanie \\
nowych \\
projektów \\
i usprawnień \\
organizacyjnych
\end{tabular} & $\begin{array}{l}\text { Opracowanie nowych } \\
\text { receptur tabliczek } \\
\text { czekolady, procesów } \\
\text { technologicznych } \\
\text { w produkcji nowych } \\
\text { rodzajów czekolady; } \\
\text { usprawnienia } \\
\text { w zakresie logistyki } \\
\text { i dystrybucji } \\
\end{array}$ & $\begin{array}{l}\text { Kierownik } \\
\text { produkcji, } \\
\text { dyrektor } \\
\text { techniczny, } \\
\text { dyrektor } \\
\text { handlowy }\end{array}$ & Proces ciągły & $\begin{array}{l}\text { Perspektywa wzrostu } \\
\text { sprzedaży poprzez } \\
\text { zdobycie nowych } \\
\text { klientów, poszerzenie } \\
\text { oferty rynkowej, } \\
\text { przyspieszenie } \\
\text { i usprawnienie dostaw } \\
\text { produktów do klientów }\end{array}$ \\
\hline $\begin{array}{l}\text { Projektowanie } \\
\text { nowych } \\
\text { technologii }\end{array}$ & $\begin{array}{l}\text { Zakup nowych linii } \\
\text { technologicznych; } \\
\text { opracowanie kolejnych } \\
\text { nowych technologii, } \\
\text { np. produkcji } \\
\text { czekolady do dalszej } \\
\text { produkcji w postaci } \\
\text { pastylek }\end{array}$ & $\begin{array}{l}\text { Właściciel, } \\
\text { dyrektor } \\
\text { techniczny, } \\
\text { kierownik } \\
\text { produkcji }\end{array}$ & Proces ciągły & $\begin{array}{l}\text { Opanowanie nowego } \\
\text { segmentu rynku - } \\
\text { małych cukierni } \\
\text { i piekarni, kontrakty } \\
\text { z dużymi odbiorcami } \\
\text { przemysłowymi } \\
\text { poszukującymi innowa- } \\
\text { cyjnych produktów } \\
\end{array}$ \\
\hline \begin{tabular}{|l|} 
Wspólne \\
opracowanie \\
sfery przemysłu \\
i sfery B+R - \\
przykład
\end{tabular} & $\begin{array}{l}\text { Pomiary rozkładu tem- } \\
\text { peratur w procesie } \\
\text { debakteryzacji ziarna } \\
\text { kakaowego, zaprojek- } \\
\text { towanie stanowisk } \\
\text { pomiarowych i badania }\end{array}$ & \begin{tabular}{|l|} 
Politechnika \\
Warszawska, \\
Instytut Techni- \\
ki Cieplnej - \\
przedsiębior- \\
stwo cukiernicze
\end{tabular} & Pół roku & $\begin{array}{l}\text { Monitorowanie prawid- } \\
\text { łowego przebiegu de- } \\
\text { bakteryzacji - potwier- } \\
\text { dzenie jakości produkcji } \\
\text { zgodnie z Systemem } \\
\text { Zarządzania Jakością }\end{array}$ \\
\hline
\end{tabular}

Źródło: opracowanie własne. ${ }_{1}$ Przedsiębiorstwo z sektora MŚP z województwa mazowieckiego - producent czekolad w tabliczkach
i czekolady do dalszej produkcji przemysłowej. 
Początkiem budowania zasobów intelektualnych w przedsiębiorstwie było pozyskanie specjalistów, którzy stali się inicjatorami dalszego dynamicznego rozwoju zasobów wiedzy. Kolejny etap uzupełniania i zdobywania wiedzy nastąpił w wyniku decyzji właścicieli i polegał na permanentnym uczeniu się poprzez udział w kursach, szkoleniach, w tym szkoleniu z zakresu zarządzania jakością prowadzonym przez Lloyd Register, w związku z wdrażaniem systemu ISO 9001. Kadra menedżerska uczestniczyła też w spotkaniach z dostawcami, innymi producentami w branży cukierniczej i firmami współpracującymi, których celem było poznanie nowych techniki i technologii, a także metod zarządzania, marketingu itd.

Zdobywanie wiedzy ma charakter ciągły, co pozwala na ciągłe modyfikacje i doskonalenie procesów w przedsiębiorstwie. Naturalną koleją rzeczy stała się konieczność powołania laboratorium zakładowego oraz tworzenie zaplecza techniczno-technologicznego dla celów projektowych czy prób w skali laboratoryjnej. Oprócz standardowego laboratorium wyposażonego w przyrządy i aparaturę laboratoryjną w przedsiębiorstwie utworzono laboratorium mikrobiologiczne. Dzięki temu mogło ono wykonywać analizy mikrobiologiczne swoich wyrobów, uzyskując oszczędności finansowe oraz przyspieszając potwierdzenie wysokiej jakości wyrobów. Kolejne fazy budowania kapitału intelektualnego przedsiębiorstwa, takie jak wprowadzanie nowych projektów i usprawnień organizacyjnych oraz projektowanie nowych technologii, były możliwe dzięki ugruntowaniu podstaw kadrowych, wzrostu i uzupełniania zasobów wiedzy w przedsiębiorstwie. Ostatnim etapem w procesie budowania kapitału intelektualnego była potrzeba współpracy z ośrodkami naukowymi ze względu na konieczność zaprojektowania i wykonania specjalistycznych badań w procesie debakteryzacji ziarna kakaowego. Efektem końcowym i wartością dodaną w przedsiębiorstwie był wzrost zasobów wiedzy - w postaci zdobytych informacji, doświadczeń oraz pojawienia się w przedsiębiorstwie potrzeby prowadzenia działań naukowo-badawczych we współpracy z jednostką naukową.

Na podstawie przedstawionej powyżej analizy struktury pierwiastka intelektualnego w przedsiębiorstwie można określić zakres czasowy budowania zasobów wiedzy w firmie MŚP, ze względu na strukturę organizacyjną przedsiębiorstwa, posiadane zasoby finansowe oraz akceptację strategii budowania zasobów wiedzy przez właścicieli i kierownictwo w firmie. W prezentowanym przedsiębiorstwie czas realizacji podstawowych etapów można określić na kilka lat, bardziej zaawansowane działania nie mają charakteru skończonych i są nadal rozwijane.

\section{Umiejętność wykorzystania zasobów wiedzy w organizacji inteligentnej}

Za propagatora idei organizacji uczących się uznawany jest Peter Senge ${ }^{2}$. Uważał on, że najważniejszą cechą organizacji inteligentnej jest umiejętność uczenia się i wykorzystania wiedzy. W aspekcie umiejętności wykorzystania zasobów wiedzy nabytej poprzez organizację można sformułować kryteria, które odnoszą działania w przedsiębiorstwie do jej zasobów wiedzy z transpozycją przyszłego rozwoju:

1. Występowanie w organizacji procesów projektowania i budowania wspólnej wizji przyszłości, która umożliwia pracownikom identyfikowanie się z organizacją i zachęca do podejmowania wyzwań.

2. Systemowe myślenie w firmie polegające na tym, że każdy pracownik dostrzega, że nie jest tylko malutkim elementem systemu, ale jest jego odbiciem i ma wpływ na wszystko, co się dzieje w firmie.

3. Firma uczy się poprzez uczenie się jednostek, czyli wszystkich pracowników. Pracownicy dążą do mistrzostwa osobistego w zakresie wykonywania swoich obowiązków oraz ciągłego rozwoju.

${ }^{2}$ Koncepcję tę Senge przedstawił w książce Piąta dyscyplina. Materiaty dla praktyka, Wyd. Wolters Kluwer, Warszawa 2007. 
4. Otwarte modele myślowe - pracownicy zdają sobie sprawę z otaczającej ich rzeczywistości, widzą, że należy odejść od stereotypów i być otwartym na innowacje. Innowacje są szczególnie istotne w przemyśle farmaceutycznym. Świadomość ta przyczynia się do rozwoju osobistego i organizacyjnego.

5. Zespołowe uczenie się ma miejsce w całej organizacji i przejawia się wspólnymi dyskusjami oraz rozwiązywaniem problemów.

6. Kodeks etyki - sprzyjający tworzeniu kultury organizacji, wpływający na poprawę relacji zarówno wewnątrz firmy, jak i z partnerami.

Charakterystycznym atrybutem organizacji inteligentnej jest umiejętność wykorzystania posiadanej wiedzy dla rozwoju organizacji. Ze względu na złożoność struktur organizacyjnych w przedsiębiorstwach wykorzystanie wiedzy powinno dotyczyć wszystkich struktur przedsiębiorstwa, zatem umiejętność dzielenia się posiadaną wiedzą i doświadczeniami z innymi pracownikami jest uzależniona od istniejących w przedsiębiorstwie kanałów dystrybucji wiedzy w firmie. Przepływ wiedzy w firmie inteligentnej powinien następować w sposób szybki, ukierunkowany oraz za pomocą dostępnych kanałów dystrybucji wiedzy. Przykładem różnych sposobów transferu wiedzy w przedsiębiorstwie mogą być:

- szkolenia,

- narady,

- spotkania tematyczne,

- tworzenie zespołów tematycznych,

- tworzenie grup projektowych,

- wykorzystanie Intranetu do szybkiego przesyłania informacji,

- tradycyjne metody przesyłania informacji: listy, pisma itd.

Wykorzystanie wiedzy przejawia się w postaci realizacji procesów innowacyjnych kreowanych w przedsiębiorstwie (Janczewska 2010), których dynamika i rodzaje wskazują na istniejące w przedsiębiorstwie zasoby kapitału intelektualnego.

Zdaniem Wziątek-Kubiak (Wziątek-Kubiak 2009), zasoby wiedzy w przedsiębiorstwie są unikalne w odniesieniu do miejsca akumulowania wiedzy i są trudne do przenoszenia poza dane przedsiębiorstwo. Pozostają zatem jej indywidualnym zasobem, dzięki czemu można przechwycić tylko część zasobów wiedzy innowatorów. Zróżnicowanie zasobów wiedzy między przedsiębiorstwami i umiejętności jej wykorzystania w wygrywaniu walki konkurencyjnej implikuje nieuchronność zróżnicowania strategii oraz efektów innowacji różnych przedsiębiorstw nawet $\mathrm{w}$ danym środowisku konkurencyjnym, przykładowo w danym kraju. To z kolei sugeruje wpływ sposobu nabywania i akumulacji wiedzy przez przedsiębiorstwa na zróżnicowanie ich strategii innowacji.

Przykładem doskonalenia procesu przepływu wiedzy w przedsiębiorstwie może być systemowe podejście do podnoszenia poziomu wiedzy w przedsiębiorstwie cukierniczym z sektora MŚP $^{3}$. W przedsiębiorstwie został utworzony system permanentnego kształcenia pracowników na wszystkich stanowiskach. Tematem szkoleń były bieżące problemy związane z jakością produkcji, doskonaleniem procesów logistycznych oraz wprowadzanie nowych metod marketingowych. Jedną z bardziej nowoczesnych form transferu wiedzy w przedsiębiorstwie było powołanie interdyscyplinarnego zespołu, którego celem było projektowanie nowych wyrobów. Przedsiębiorstwo odeszło od tradycyjnej koncepcji powierzenia zadania opracowania nowych wyrobów technologowi czy kierownikowi laboratorium. W skład grupy projektowej weszli przedstawiciele wszystkich działów organizacyjnych przedsiębiorstwa, których zadaniem było wspólne opracowanie nowego produktu i określenie możliwości jego zrealizowania z punktu

\footnotetext{
${ }^{3}$ Przedsiębiorstwo z sektora MŚP - producent cukierków z województwa łódzkiego.
} 
widzenia danego działu (proces opracowania nowego produktu pokazuje ryc. 1). Celem stworzenia takiej struktury zespołu była wymiana zasobów wiedzy zlokalizowanych w poszczególnych działach organizacyjnych przedsiębiorstwa oraz wykreowanie nowych metod zarządzania innowacyjnego $\mathrm{w}$ przedsiębiorstwie.

Proces opracowania nowego produktu realizowano w okresie trzech miesięcy w zespole wieloosobowym, w którym wszyscy uczestnicy mieli prawo wygłaszania swoich poglądów oraz koncepcji. Dział marketingu przedstawił wyniki badania nabywców oraz wskazał na najważniejsze sugestie i oczekiwania wobec nowego produktu: smak, wygląd, rodzaj opakowania, forma dystrybucji oraz perspektywy sprzedaży nowego produktu. Zapoznał zespół z możliwościami pozyskania surowców, opakowań oraz przedstawił propozycje dotyczące doboru firm kooperujących. Dział produkcji określił możliwości techniczne, technologiczne oraz przewidywane trudności i komplikacje w procesie produkcji. Rola działu księgowości polegała na określeniu możliwości finansowych zakładu i wyrażeniu opinii na temat kalkulacji cenowej produktu i rachunku kosztów jego wytworzenia oraz dystrybucji.

Efektem zastosowanego sposobu organizacji procesu tworzenia nowego produktu był wzrost zasobów wiedzy w całej organizacji, w poszczególnych jej działach, powiększony o wiedzę przekazaną w trakcie dyskusji i narad przez innych pracowników spoza grupy projektowej. Dodatkowym efektem synergicznym było powstanie nowych zasobów wiedzy wśród pozostałych pracowników przedsiębiorstwa, biorących udział w dyskusji czy zgłaszających własne koncepcje i pomysły. Kanałem transferu wiedzy w przedsiębiorstwie był również Intranet, który przyspieszał wymianę informacji czy też umożliwiał szybką wymianę zapisów, wyliczeń, wzorów opakowań lub nowych informacji od klientów.

Ryc. 1. Proces opracowania nowego produktu w zespole interdyscyplinarnym w przedsiębiorstwie uczącym się

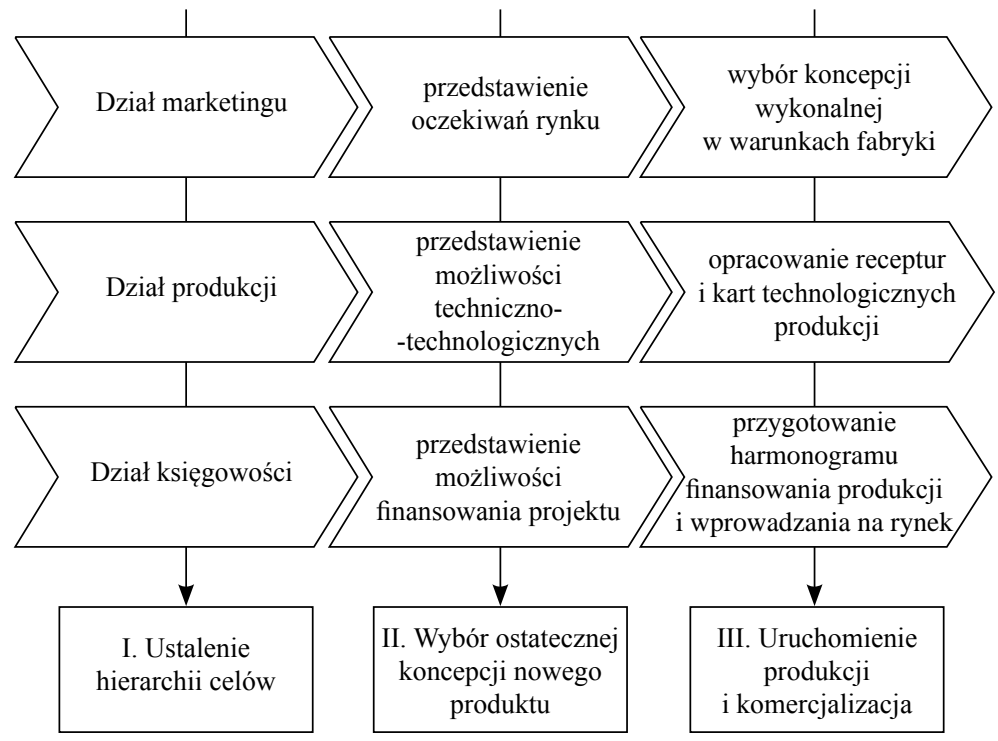

Źródło: opracowanie własne. 


\section{Zarządzanie kapitałem intelektualnym w przedsiębiorstwie MŚP}

Kapitał intelektualny w przedsiębiorstwie uczącym się może być traktowany jako zasób przedsiębiorstwa, a proces tworzenia kapitału może być zdefiniowany w ujęciu procesowym. W organizacji inteligentnej ma on charakter ciągły i wiąże się z monitorowaniem efektów w organizacji. Metody pomiaru proponowane w literaturze przedmiotu dotyczą przedsiębiorstw dużych (Edvinsson, Malone 2001), czego przykładem może być Model Scandii opracowany w celu wyceny kapitału intelektualnego przedsiębiorstw przez skandynawskie przedsiębiorstwo ubezpieczeniowe Scandia. Metoda pomiaru zwana Nawigatorem Scandii jest jednak skomplikowana i niezbyt przystająca do zastosowania w przedsiębiorstwach MŚP.

Model duński, opracowany przez Ministerstwo Handlu i Przemysłu oraz Duńską Agencję Handlu i Przemysłu, definiuje diagnozę kapitału intelektualnego poprzez ocenę zasobów przedsiębiorstwa i ocenę efektów oraz propozycje działań (Bukowitz, Wiliams 2000). Rezultaty diagnozy opartej na modelu duńskim koncentrują się wokół efektów niematerialnych: satysfakcja, lojalność, doświadczenie, których wzrost prowadzi do wzrostu wartości przedsiębiorstwa.

Model duński może być zastosowany do zarządzania kapitałem intelektualnym w firmie MŚP ze względu na jego uniwersalny zakres oraz możliwość dostosowania do realiów małej firmy. Podejście oparte na tym modelu wymaga opisu stanu dzisiejszego w przedsiębiorstwie, wyboru właściwych działań oraz prezentacji i pomiaru rezultatów (Piertuszka-Ortyl 2002).

Opis stanu dzisiejszego przedsiębiorstwa MŚP wymaga identyfikacji zasobów, takich jak:

- zasoby ludzkie: liczba pracowników z wyższym wykształceniem, liczba osób posiadających odpowiednie kwalifikacje, liczba pracowników uzupełniających wykształcenie itd.,

- klienci: liczba klientów i ich segmentacja, charakterystyka relacji z grupami klientów,

- technologia: stosowane metody wytwarzania lub świadczenia usług,

- procesy: opis procesów realizowanych w przedsiębiorstwie.

Wybór działań zwiększających zasób kapitału intelektualnego w przedsiębiorstwie obejmuje podnoszenie poziomu wykształcenia pracowników, ocenę i ekspertyzę działań technologicznych, rozwój relacji z klientami. Rezultaty podjętych działań powinny być oceniane poprzez pomiar satysfakcji, lojalności, doświadczeń nabytych podczas realizacji działań oraz wzrostu wartości przedsiębiorstwa.

Duński model diagnozy kapitału intelektualnego przedsiębiorstwa może być przydatny do zarządzania kapitałem intelektualnym w firmie MŚP. Daje on możliwość elastycznego dopasowania wybranych wskaźników charakteryzujących przedsiębiorstwo MŚP, a następnie indywidualnego podejścia do metod zwiększania kapitału intelektualnego. Wskazane jest poszukiwanie indywidualnych, własnych metod pomiaru kapitału intelektualnego w przedsiębiorstwie oraz odniesienie do warunków otoczenia, w których funkcjonuje przedsiębiorstwo, np. w ujęciu sektorowym.

Uwarunkowania rozwoju przedsiębiorstwa uczącego się na przykładzie sektora MŚP jest zagadnieniem rzadko spotykanym w literaturze przedmiotu. Sektor MŚP nie jest traktowany jako sektor innowacyjny, zdolny do kreowania nowych produktów czy procesów, a badania zjawisk występujących w sektorze trwają od niedawna i mają głównie charakter poszukiwania wskaźników ilościowych.

Przedsiębiorcy działający w sektorze MŚP są postrzegani jako osoby nieposiadające strategii rozwoju własnych firm, niechętnie wprowadzające innowacje czy poszukujące informacji. Wskazywanie możliwości rozwoju przedsiębiorstwa MŚP w kierunku budowania zasobów wiedzy jest w pewnym stopniu uzasadnione, bo jest to rozwój mniej kapitałochłonny niż inwestycje w budynki czy maszyny. Przykłady przedsiębiorstw z branży cukierniczej potwierdzają, 
że podejmowanie inicjatyw zmierzających do budowania zasobów wiedzy sprzyja rozwojowi przedsiębiorstw z sektora MŚP. Tak ukierunkowany rozwój przedsiębiorstw z sektora MŚP jest obecnie wspierany przez inicjatywy Unii Europejskiej oraz programy oferujące środki finansowe na wzrost zasobów wiedzy.

\section{Literatura}

1. Boisot M., Canals A., 2004, Data, information and knowledge: have we got it right?, „Journal of Evolutionary Economics", vol. 14, no. 1, s. 43-47.

2. Białoń L., Janczewska D. 2007, Wiedzochłonność procesów innowacyjnych. Część I, „Postępy Techniki Przetwórstwa Spożywczego", nr 2, tom 17/31, s. 93-97.

3. Bukowitz W.R., Wiliams R.L., 2000, The Knowledge Management Fieldbook, Financial Time, Prentice Hall, London.

4. Edvinsson L., Malone M.S.,2001, Kapitat intelektualny, Wydawnictwo Naukowe PWN, Warszawa.

5. Grudzewski W., Hejduk I. 1999, Kreowanie przedsiębiorstwa przyszłości z wykorzystaniem teorii i praktyki organizacji inteligentnej [w:] Przedsiębiorstwo wobec wyzwań przyszłości, M. Haffer, S. Sudoł (red.), Wyd. Komitet Nauk Organizacji i Zarządzania PAN, Uniwersytet Mikołaja Kopernika, Wydział Nauk Ekonomicznych i Zarządzania, Toruń.

6. Janczewska D., 2010, Podnoszenie konkurencyjności MŚP poprzez transfer wiedzy z jednostek nauki do zastosowań praktycznych $w$ regionie [w:] Szkoły wyższe w gospodarce regionów, J. Wernik, K. Wołosz (red.), Wyd. Oficyna Wydawnicza Politechniki Warszawskiej, Warszawa.

7. PARP, 2010, Raport o stanie sektora matych i średnich przedsiębiorstw w Polsce $w$ latach 2008-2009, Warszawa.

8. Penc J., 2000, Menedżer w uczącej się organizacji, Wyd. Menedżer, Łódź.

9. Pietruszka-Ortyl A., 2002, Model diagnozy kapitału intelektualnego organizacji [w:] Zarzadzanie przedsiębiorstwem XXI wieku, B. Mikuła, A. Pietruszka-Ortyl, A. Potocki, Wyd. Difin, Warszawa.

10. Plawgo B., Wyksztatcenie pracowników a konkurencyjność przedsiębiorstwa - referat wygłoszony na konferencji PARP, Warszawa 16.11.2010.

11. Pomykalski A., 2001, Zarzadzanie innowacjami, Wydawnictwo Naukowe PWN, Warszawa.

12. Senge P.M., 2007, Piąta dyscyplina. Materiaty dla praktyka, Wydawnictwo Wolters Kluwer Polska Sp. z o.o., Warszawa.

13. Sulmicka M., 2010, Ekspertyza „Priorytety i cele rozwojowe UE do 2020 w kontekście aktualizacji średniookresowej strategii rozwoju kraju”, Szkoła Główna Handlowa, Warszawa.

14. Wziątek-Kubiak A., 2009, Od awersji do innowacji do upowszechnienia się innowacji wśród polskich przedsiębiorstw [w:] Polska transformacja po latach, E. Adamowicz (red.), wyd. C.H. Beck, Warszawa. 


\section{Determinants of development of the learning enterprise based on the example of SMEs sector}

Dynamic changes of the market and broadly defined environment of the enterprise are forcing to seek out for new directions of enterprise development in the SMEs sector. One of the current methods to raise the competitive position is to enhance entrepreneurship and business activities by learning of organization. The term of learning organization or intelligent organization can be defined as a process of building comprehensive solutions in an enterprise by developing a communication and information structure as well as interactions between participants of the system. The learning organization is based on summary of knowledge coming from individual employees. It is also possible to define some characteristic features derived from specific actions within the management area. The distinctive attribute of the intelligent organization is its ability to utilize already acquired knowledge for the benefit of organization development. Due to complexity of the organizational structures, the knowledge application should concern all the structures of the enterprise. Therefore, the ability to share the acquired knowledge and experience with other employees depends on existing distribution channels of knowledge in the company. The own studies show that SMEs enterprises tend to create individual methods of building the knowledge capital by using the modern information systems. 